\title{
Towards Translation Naturalism at Translation of English Film Production into Modern German
}

\author{
Yuriy V. Kobenko \\ National Research Tomsk Polytechnic University \\ Email: serpentis@tpu.ru \\ Nataliya N. Zyablova \\ National Research Tomsk Polytechnic University \\ Email: zyablova@tpu.ru \\ Svetlana I. Gorbachevskaya \\ Moscow State University \\ Email: sgaeiou@yandex.ru
}

Doi:10.5901/mjss.2015.v6n3s2p494

\section{Abstract}

The article informs about modern tendencies in synchronous translation into German connected with the influence of American culture. Modern American-British English and German are similar in formation of vocabulary but different in the way of reality description which explains the presence of interference and substitution of registers at translation. Besides, synchronizers are placed in tight time limits and translation is not always made by people with relevant qualification which worsens the problem. More than that, 'hidden Anglicism' is taken by viewers as fashionable stylistic transformation and unconscious imitation of American culture begins to appear in the way of actualization and choice of means of expression in speech and text. However, the risk is not in the choice of means of expression for synchronization but properly in translator's becoming automatically a legislator of language norm due to broadcasting a text of translation via TV whereas a channel functions as an authoritative source.

Keywords: translation naturalism, recipient language, donor language, Anglo-Americanisms, film and video production.

\section{Introduction}

Naturalism is a special way of taking Anglo-Americanisms into modern German at translation. Peculiarities of translation film and video production of the USA which dominate European market for some decades need highlighting in this context. According to the data of a committee 'EvrAktiv' in 2009 it comprised $60 \%$ of all serial films and so called 'soap operas', $55.7 \%$ of all fictional films, $49.3 \%$ of TV movies and $45.4 \%$ of cartoons. Such increase of American products of cinema and TV industry not only greatly decreases quality of translation but also causes standard ways and stereotypes of interpretation of content which enable transfer of foreign units.

\subsection{Research Methods}

Scientific methods: inductive, deductive and quantitative and a linguistic method: comparative were used.

\section{Analysis}

Taking units of modern American-British English (the term was invented by S. Pinker [2]) by synchronous interpretation happens more intensively rather than consecutive one (not duplicate one) as sound-on-film should be made during limited time. In this way German goes on to lose to American-British English because of its circumstantiality. As a consequence of it a translator chooses a more compact way of translation thus putting verbal forms of recipient language to contextual compression. Therefore, the main idea is in semantic taking as a result of translation of American film and 
video production and influence of taken units of American-British English on the language norm of standard German.

Such units are not neologisms in German as they only substitute the outer part of the existing lexemes. Nonspecialists do not take into account inadequacy of synchronization while the problem is obvious: possibilities of German itself become not actual or disappear as a result of introduction of anglicized calques. It is necessary to mention that $\mathrm{E}$. $\mathrm{G}$. Riesel' eliminated a particular kind of taken units conserved at translation into a form of citations only for making a cultural color [3, p. 114].

Let us give consideration to consequences of translation naturalism as exemplified in three groups: a) false friends; b) polysemy; c) component-by-component calquing. Material was taken from American fiction films televised on 'Pro 7' channel from 1997 to 2007 in German synchronization.

a) So, a positive transfer of elements with similar phonation is caused by homology of German and English. Pairs 'scheu' and 'schüchtern', 'fett' and 'dick', 'weise' and 'klug' are semantically similar but they are not absolute synonyms. However, such semantic-stylistic nuances in German strongly disappear under automatic identification of English 'shy' with German 'scheu', 'fat' with 'fett', 'wise' with 'weise' at translation. It is curiously enough that it occurs there where 'schüchtern', 'dick', 'klug' could covey the meaning more accurately and completely. The reason is formal resemblance of 'shy' and 'scheu', 'fat' and 'fett', 'wise' and 'weise', which causes incorrect acceptance of these pairs as language equivalents [5]. Such phenomenon in science of translation is known as pseudo relation and lexical units are called false friends (falsche Freunde in German). There are a lot of examples of such identification: the meaning of the word 'der Rest' (similar to English 'rest') is equal to 'übrige / das Übrige', whereas in German nuances <Vervollständigung> and <sonst noch Vorhandenes> characterize it; 'Konsequenz' (similar to English consequence) fully substitutes 'Folge', whereas there is a distinct difference 'Konsequenzen ziehen (aus jemandes Verhalten)', 'Folgen ergeben sich (aus Ursachen)'; a word 'Rebellen' belonged to a poetic register from the time of F. Schiller in contrast with stylistically neutral 'Aufständische', however, stylistic marker was lost under the influence of English 'rebels'; a verb 'beherrschen' is seldom used for 'cope' due to its unthought change into a verb 'kontrollieren' which expresses less degree of coping and was initially used as a synonym of a word 'überprüfen'.

b) The second group describes the cases of unreasonable introduction of allonyms into a final text. Allonym is a change of usual construction of recipient language into conventional one in donor language but as a minimum not known in recipient language which is motivated with insufficient knowledge of possibilities in own language. For instance, there is only indiscrete meaning experience for German words 'Erfahrung' and 'Erlebnis' in English. However, only one variant 'Erfahrung' is used more often at translation into German, despite the difference between 'Erfahrung' and 'Erlebnis' is very significant, for instance, it is impossible to say 'das Konzert war eine Erfahrung'. There are similar processes at translation of English 'survive / survival' into a German noun and verb 'Ü/überleben', whereas words 'fortbestehen' and 'Fortbestand', which are often more adequate at translation (especially in combination with 'Verhältnisse, 'Umstände'), are less in use. It seems 'Obwohl' became a single translation of English '(al)though' even in compound constructions where the only use of German adverb 'zwar' is correct. A German word 'einige' does not always correspond to English 'some'; indefinite numeral 'manche' is semantically and stylistically correct. A popular expression 'Jemand arbeitet für die Regierung' is a typical example of allonym at translation. The sentence is slightly pompous and makes a connotation 'governmental covert activity'. However, in reality the speech is about a government (Staat in German) and civil service (Staatsdienst in German). Therefore, 'Jemand ist beim Staat angestellt' is a correct variant of translation as a verb 'work' makes self-perception of the expression more complicated. Translation 'Körper' for English 'body' is a little obscure in case the last is used in the meaning <corpse>. There is a more adequate word 'Leiche' in German for that which, by the way, is often ignored at synchronization. To our opinion, the reason is influence of American police jargon elements of which are used absolutely without a reasonable basis instead of standard denotations by translators for so-called 'naturality' of situation.

Transformation of meaning of a chosen variant in recipient language or decrease / increase of its stylistic nominal is common for both groups. It is evident that unjustified naturalism with elements of 'overt translation' after J. House are taken as a basis of translation which consequence is a factual change of means of expression of recipient language with those ones of donor language and not textual sequence which determines effect of perception of translated facts [1]. Unconscious imitation of American culture is obvious both in the way of actualization and choice of means of expression in speech and text. However, the risk is not in the choice of means of expression for synchronization but properly in translator's becoming automatically a legislator of language norm due to broadcasting a text of translation via TV whereas a channel functions as an authoritative source. So and no in other way could be added a 'hidden Anglicism' 'Besserwisser' (modern American-British English: who ought to know better) which afterwards started competing 
successfully with each element of synonymic row to already existing 12 synonyms of a word 'Neunmalkluger' (know-all in German) [4].

c) The third group is represented by so-called non-system word formations revealing clear formalist preferences of translators at interpretation of modern American-British English units, for instance: 'Babymaus', 'Babykrokodil' and so on (by analogy with 'baby mouse', 'baby crocodile') instead of 'Mäuse-, Krokodilbaby, junges'. The question 'Wer war es?' is usually answered 'Nicht ich' / 'Nicht Peter' (modern American-British English: 'Not me' / 'Not Peter') instead of usual 'Ich nicht' / 'Peter nicht'; 'Kannst du uns sehen / hören?' (modern American-British English: 'Can you see / hear us?') instead of 'Siehst / Hörst du uns?'. The following phenomena are not typical for German: 'Mach deine Augen auf!', 'Er schließt seinen Mund' (modern AmericanBritish English: ... your eyes, ... his mouth) instead of usual constructions with the definite article having possessive function in German; contraction of reflection with the definite article is very common for expressions like: 'Du hast mein Leben gerettet' (modern American-British English: ... my life) instead of ... mir das Leben. Use of 'wirklich' and 'eigentlich' is non-system enough in contexts with negation of something where variant 'eigentlich nicht' and not a copy of English a 'nicht wirklich' (modern American-British English: not really) is correct, however, there where 'wirklich' is recommended there is an allonym construction 'Bist du sicher, dass ...?' (modern American-British English: Are you sure...?). Imperative sentences with a particle doch are changed into question constructions 'Warum [...] nicht?' (modern American-British English: Why don't ... ?), for instance: 'Warum setzen wir uns nicht?' instead of 'Setzen wir uns doch!'. The following cases are frequent: 'Alles, was ich brauche, ist...' instead of 'Ich brauche (sonst) nichts als ...'; 'unglücklicherweise' (modern American-British English: unfortunately) and 'ich fürchte, dass ...' (modern American-British English: I'm afraid ...) usually take initial position instead of 'leider'; construction 'Wenn ich du wäre' (modern AmericanBritish English: if I were you) gradually displaces usual 'ich an deiner Stelle'. Formalism of synchronizers makes no exceptions at calquing of words and constructions which are behind original German words in laconism and clarity: so, a word combination 'menschliche Wesen' (modern American-British English: human beings) can be heard instead of 'Menschen' which, in our opinion, fully deconcretizes meaning 'man' in German. Construction '... wurde(n) (bei einem Unfall, einer Naturkatastrophe) getötet' conrtadicts semantics of 'töten' used for describing wilful murder. Short 'weltweit' (modern American-British English: worldwide) absolutely changed once-habitual 'weltumspannend'. Verb 'klingen' have come under use in the first and second singular and plural: 'du klingst überrascht' by analogy with 'you sound surprised'.

\section{Analysis Result}

Arguments against such synchronization have repeatedly been argued by language societies in Germany. However strange though it may appear a viewer is interested in 'bad' translation asking for natural explication of aggressive American culture. Modern American-British English and German are similar in vocabulary formation but different in the way of reality description. This explains the presence of interference and substitution of registers at translation. The problem is made worse with the fact that synchronizers are placed in tight time limits and translation is not always made by people with relevant qualification. 'Hidden Anglicism' is taken by viewers as fashionable stylistic transformation needed to be actively imitated and not as translation bloopers. Translators in their turn try 'to conserve' foreign words by means of retaining their original form to probably exclude ambiguity at translation into German system or creation of a definite color of speech by means of presentation of an element of 'Borrowed'. However, such phenomena have a character of citations without adequate translation into a recipient language and create a feeling of different cultural environment and destroy lexical-semantic architecture of a text without being as such in reality.

\section{References}

House J. Pragmatic Competence in Lingua Franca English / Knapp Karlfried, Meierkord Christiane (eds.) Lingua Franca Communication. - Frankfurt am Main, 2002. - P. 245-267.

Pinker S. Words and Rules: The Ingredients of Language. - NY, 1999. - pp. 348.

Riesel E. Stilistik der deutschen Sprache. - Moskau: Verlag für fremdsprachige Literatur, 1959. - 468 S.

Kobenko Ju.V., Zyablova N.N. Strukturnye osobennosti terminologicheskih akronimov v tekstah anglijskogo nauchno-tehnicheskogo stilja sfery vozobnovljaemyh istochnikov jenergii // Filologicheskie nauki: voprosy teorii i praktiki. — № 5(1). — Tambov: Gramota, 2013. - pp. 71-73.

Kobenko Yu.V., Ptashkin A.S. Equivalence and Appropriateness: Divergence Characteristics of Categories under Translation /I Mediterranean Journal of Social Sciences. - 2014. - Vol. 5. — No 27. — pp. 1694-1697. — [Access mode: http://mcser.org /journal/index.php/ mjss/article/view/5244 (date of treatment: 30.01.2015)]. 